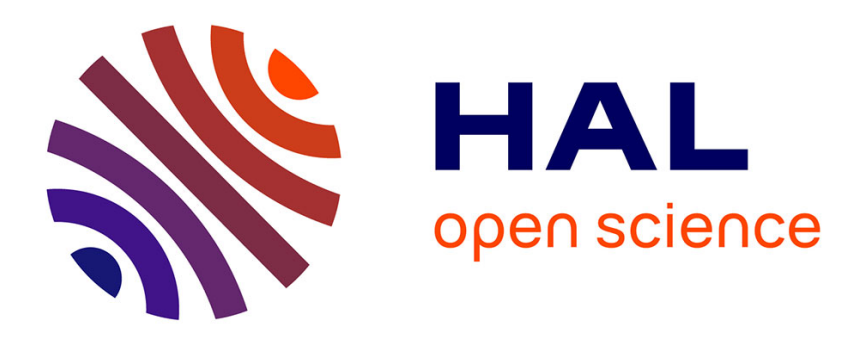

\title{
Unraveling mysteries of hydrogen electrooxidation in anion exchange membrane fuel cells
}

\author{
Dario G Dekel
}

\section{To cite this version:}

Dario G Dekel. Unraveling mysteries of hydrogen electrooxidation in anion exchange membrane fuel cells. Current Opinion in Electrochemistry, 2018, 12, pp.182-188. 10.1016/j.coelec.2018.11.013 . hal02003792

\section{HAL Id: hal-02003792 \\ https://hal.science/hal-02003792}

Submitted on 12 Feb 2019

HAL is a multi-disciplinary open access archive for the deposit and dissemination of scientific research documents, whether they are published or not. The documents may come from teaching and research institutions in France or abroad, or from public or private research centers.
L'archive ouverte pluridisciplinaire HAL, est destinée au dépôt et à la diffusion de documents scientifiques de niveau recherche, publiés ou non, émanant des établissements d'enseignement et de recherche français ou étrangers, des laboratoires publics ou privés. 


\section{AUTHOR QUERY FORM}

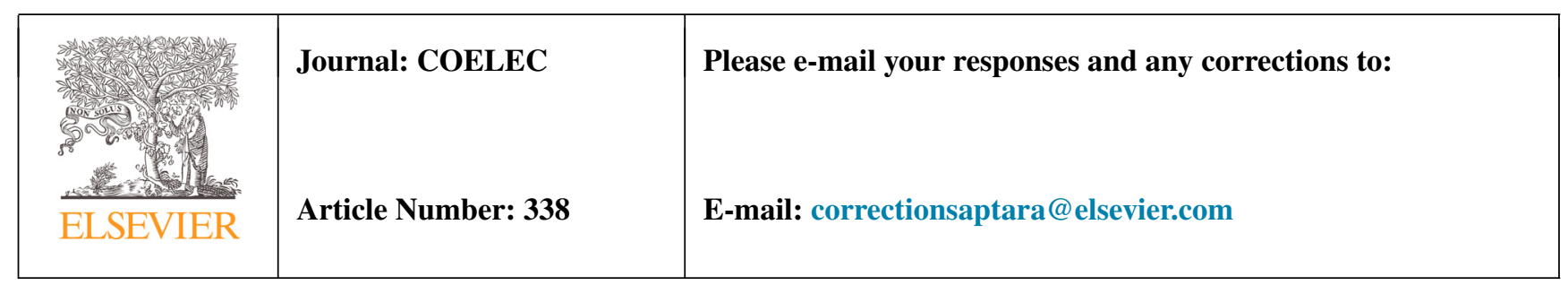

Dear Author,

Please check your proof carefully and mark all corrections at the appropriate place in the proof (e.g., by using on-screen annotation in the PDF file) or compile them in a separate list. Note: if you opt to annotate the file with software other than Adobe Reader then please also highlight the appropriate place in the PDF file. To ensure fast publication of your paper please return your corrections within 48 hours.

Your article is registered as belonging to the Special Issue/Collection entitled "Vol 12 Fuel Cells and Electrolyzers 2018". If this is NOT correct and your article is a regular item or belongs to a different Special Issue please contact s.alagesan@elsevier.com immediately prior to returning your corrections.

For correction or revision of any artwork, please consult http://www.elsevier.com/artworkinstructions

Any queries or remarks that have arisen during the processing of your manuscript are listed below and highlighted by flags in the proof. Click on the ' $Q$ ' link to go to the location in the proof.

\begin{tabular}{|c|c|c|}
\hline $\begin{array}{l}\text { Location } \\
\text { in article }\end{array}$ & \multicolumn{2}{|c|}{$\begin{array}{l}\text { Query / Remark: click on the Q link to go } \\
\text { Please insert your reply or correction at the corresponding line in the proof }\end{array}$} \\
\hline Q1 & \multicolumn{2}{|c|}{$\begin{array}{l}\text { AU: The author names have been tagged as given names and surnames (surnames are highlighted in teal } \\
\text { color). Please confirm if they have been identified correctly. }\end{array}$} \\
\hline Q2 & \multicolumn{2}{|l|}{ AU: Please validate the author affiliation. } \\
\hline Q3 & \multicolumn{2}{|l|}{ AU: Please provide "Conflict of interest" section as per the JSS requirement. } \\
\hline Q4 & \multicolumn{2}{|c|}{$\begin{array}{l}\text { AU: Please provide the Grant numbers for the given Grant sponsors "GTEP" and "Melvyn \& Carolyn } \\
\text { Miller Fund for Innovation". }\end{array}$} \\
\hline Q5 & \multicolumn{2}{|l|}{ AU: Please validate the given Grant sponsors for correctness. } \\
\hline Q6 & \multicolumn{2}{|l|}{ AU: Please provide volume no. and page range in Refs. $[7,15,16 \bullet, 21]$. } \\
\hline & $\begin{array}{l}\text { Please check this box or indicate your approval if } \\
\text { you have no corrections to make to the PDF file }\end{array}$ & \\
\hline
\end{tabular}

Thank you for your assistance. 


\section{Graphical Abstract}

Unraveling mysteries of hydrogen electrooxidation in anion
exchange membrane fuel cells
Dario R. Dekel*
The Wolfson Department of Chemical Engineering, The Nancy \& Stephan Grand
Technion Energy Program, Technion - Israel Institute of Technology, Haifa
3200003, Israel




\section{Review Article \\ Unraveling mysteries of hydrogen electrooxidation in anion exchange membrane fuel cells}

\section{Anion exchange membrane fuel cells (AEMFCs) can potentially revolutionize the energy generation market; however, to be seriously considered as a real alternative to the mainstream fuel cell technology, complete removal of previous metal electrocatalysts needs to be achieved. While in cathode electrodes platinum can be easily substituted, the electrochemical hydrogen oxidation reaction $(\mathrm{HOR})$ in the AEMFC anodes currently involves prohibitive overpotential losses, making the removal of platinum extremely challenging. Understanding the HOR in AEMFCs will facilitate the path to overcome the challenge and finally develop and demonstrate platinum-free high-performance AEMFC devices.}

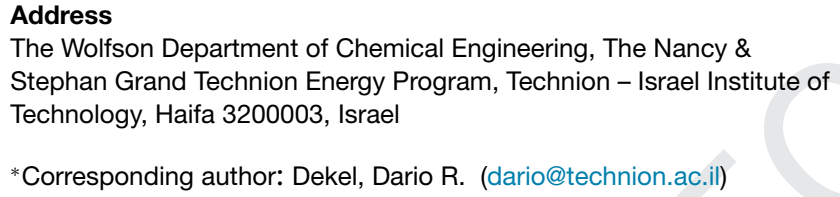

\section{Introduction}

There is an increasing worldwide interest in anion exchange membrane fuel cells (AEMFCs), as the technology promises significant reduction in costs by avoiding the use of platinum as electrocatalysts $\left[1^{\bullet \bullet}-4\right]$. Very recently, extensive research in hydrogen AEMFCs led to significant progress in cell performance of this technology $\left[5^{\circ \bullet}-10\right]$, and to an important increasing in the understanding of the main current challenges - membrane degradation/performance stability $\left[11-16^{\circ}\right]$ and $\mathrm{CO}_{2}$ effect on AEMFC performance [17-24]. This recent progress and the numerous achievements reached in the past years in the technology, suggest that AEMFC can now be considered as a serious alternative to the counterpart proton exchange membrane fuel cells (PEMFCs), but potentially without expensive electrocatalysts in their cells. In this front however, while for oxygen reduction reaction there are already several potentially good nonprecious metal electrocatalyst alternatives under study [25-29], for the hydrogen oxidation reaction (HOR) at the anode of AEMFCs it seems that the challenge is considerably higher, and the way to achieve high anode performance based on low cost, non-PGM catalysts is still very long $\left[30^{\circ}\right]$. The ability to understand and resolve the challenge of hydrogen electrooxidation in AEMFC, in order to develop electrocatalysts highly active towards HOR, is crucial for the future of the AEMFC technology $\left[5^{\bullet \bullet}, 30^{\bullet \bullet}, 31\right]$.

\section{About the challenging HOR in AEMFC alkaline environment}

The electrochemical reactions of hydrogen oxidation differ, depending on the medium, as shown below. In acidic and alkaline environment, the HOR is given by:

$\mathrm{H}_{2} \rightarrow 2 \mathrm{H}^{+}+2 \mathrm{e}^{-} \quad$ [acidic medium in PEMFCs]

$\mathrm{H}_{2}+2 \mathrm{OH}^{-} \rightarrow 2 \mathrm{H}_{2} \mathrm{O}+2 \mathrm{e}^{-} \quad$ [alkaline medium in AEMFCs]

The HOR in the acidic medium (Equation (1)) has been well studied, as this electrochemical reaction is of fundamental importance in electrochemistry and electrochemical devices, including PEMFCs. Numerous studies showing different aspects of this reaction have been published [32-34]. Researchers found that the kinetic rates and activities of different electrocatalytic materials towards HOR in acidic medium, are strongly correlated to the hydrogen energy bonding (HEB) of the adsorbed hydrogen $\left(\mathrm{H}_{\mathrm{ad}}\right)$ onto the catalyst surface [33-35].

In contrast, the HOR in alkaline medium (Equation (2)), although also a reaction of central importance in the electrochemical field, has been scarcely studied. A recent comprehensive review of the current understanding of HOR electrocatalysis in basic medium describes in details the research studies done in this field, highlighting the challenges involved in developing new materials with high activity in this medium $\left[30^{\circ \bullet}\right]$. In their review, the authors also focused on the kinetics and the reaction mechanisms of HOR in alkaline medium. Several research 

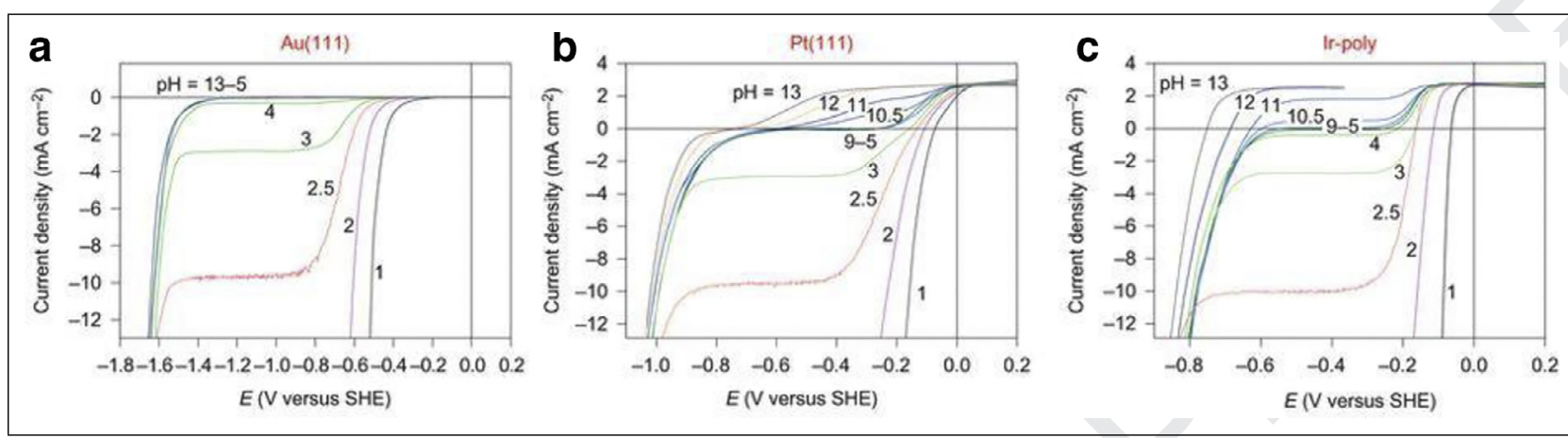

Measured polarization curves for $\mathrm{pH}=1-13$ for (a) $\mathrm{Au}(111)$, (a), $\mathrm{Pt}(111)$ (b) and Ir-poly. Adopted from [390].

studies have shown that the kinetics of the HOR in alkaline media is much slower than in acidic solutions $\left[36,37^{\circ}\right]$. For instance, the HOR activity of carbon-supported noble metals ( $\mathrm{Pt}, \mathrm{Pd}$ and $\mathrm{Ir}$ ) decreases by around two orders of magnitude when transitioning from low to high $\mathrm{pH}$ [38]. The HOR kinetics changes with the $\mathrm{pH}$ of the medium were clearly shown by Strmcnik $e t$ al. [39 $\left.{ }^{\circ}\right]$. The authors presented a series of experimental measured polarization curves for the HOR on different catalytic materials in a wide range of $\mathrm{pH}(1<\mathrm{pH}<13)$, as shown in Figure 1. Clear differences between the measured current densities at $\mathrm{pH}<3$ and $\mathrm{pH}>11$ can be seen.

The authors also performed a simulation of the polarization curves using a simple set of electrochemical equations, confirming the experimental results shown in Figure 1. Results revealed that in strong acidic medium $(\mathrm{pH}<3$, corresponding to acidic environment of PEMFCs) the HOR proceeds through the direct oxidation of hydrogen to $\mathrm{H}^{+}$(Equation (1)); while in strong alkaline medium $(\mathrm{pH}>13$, corresponding to acidic environment of AEMFCs), pure diffusion-limiting currents are also observed. As mentioned by the authors, this suggests that in alkaline medium, the supply for both hydrogen and hydroxide anions (both reactants in the HOR in AEMFCs, see Equation (2)) are sufficient to maximize the electrochemical oxidation of hydrogen to water. We can then also say that as the $\mathrm{pH}$ in the environment is increased, an increase in the diffusion-limiting currents is obtained. In other words, as the $\mathrm{OH}^{-}$concentration in the fuel cell is higher, purer diffusion-limiting currents will be observed, indicating then that the $\mathrm{OH}^{-}$plays an important role in the HOR for AEMFCs. What is the best way to quantify this role of the $\mathrm{OH}^{-}$is not yet clear.

\section{Is HBE descriptor good enough to evaluate HOR catalyst for AEMFCs?}

As shown in Equation (2), in AEMFCs the electrochemical oxidation of hydrogen involves two reactants - hydrogen and hydroxide anions - instead of only one reactant for the acidic counterpart (Equation (1)) - hydrogen. As hydrogen is a reactant for both acidic and alkaline fuel cells, the differences in the kinetics rates for the HOR on different electrocatalysts in both systems are sometimes attempted to be explained by the variation in HBE values [40]. Although differences in HBE mostly succeed to explain kinetics variations for PEMFCs, in the alkaline counterpart the situation seems to be more complex [37 $]$.

The best catalysts for HOR in acidic PEMFCs are those with an optimal interaction between the catalytic substrate and the $\mathrm{H}_{\mathrm{ad}}$ species, that usually is quantified by the HBE. Similarly, it was proposed that the role of the $\mathrm{OH}^{-}$in the HOR in alkaline medium can be related to the $\mathrm{OH}_{\text {ad }}$ properties of the catalyst $\left[39^{\circ}\right]$. In other words, it was suggested that fine-tuning of the adsorption energy of $\mathrm{OH}_{\mathrm{ad}}$ could be a new way to quantify HOR in AEMFC systems [ $\left.3^{\circ}{ }^{\circ}\right]$. To quantify this energy, Davydova et al. $\left[30^{\circ}\right]$ proposed to calculate a new descriptor called OHBE - $\mathrm{OH}_{\mathrm{ad}}$ binding energy - and compare it to the HBE for each electrocatalyst system. Similar to what has been suggested by Koper [41], for some electrocatalytic systems, both HBE and OHBE are expected to be interconnected, as the presence of $\mathrm{OH}_{\mathrm{ad}}$ is probable to improve the reactivity of the adsorbed hydrogen intermediated $\mathrm{H}_{\mathrm{ad}}$, enhancing the overall reactivity of HOR, and vice versa. In other words, if this basic idea is correct, it means that the best electrocatalysts for HOR in alkaline AEMFCs are those with an optimal interaction between the catalytic substrate and both the $\mathrm{H}_{\mathrm{ad}}$ and $\mathrm{OH}_{\mathrm{ad}}$ species, evaluated by the HBE and OHBE descriptors, respectively. What exactly is the relationship between HBE and OHBE, and how close they are interconnected each other, is currently an unknown.

Very recently, Davydova et al. [42] first attempted to evaluate both HBE and OHBE descriptors on their HOR electrocatalysts for AEMFCs (see Figure 2). The authors 
Figure 2

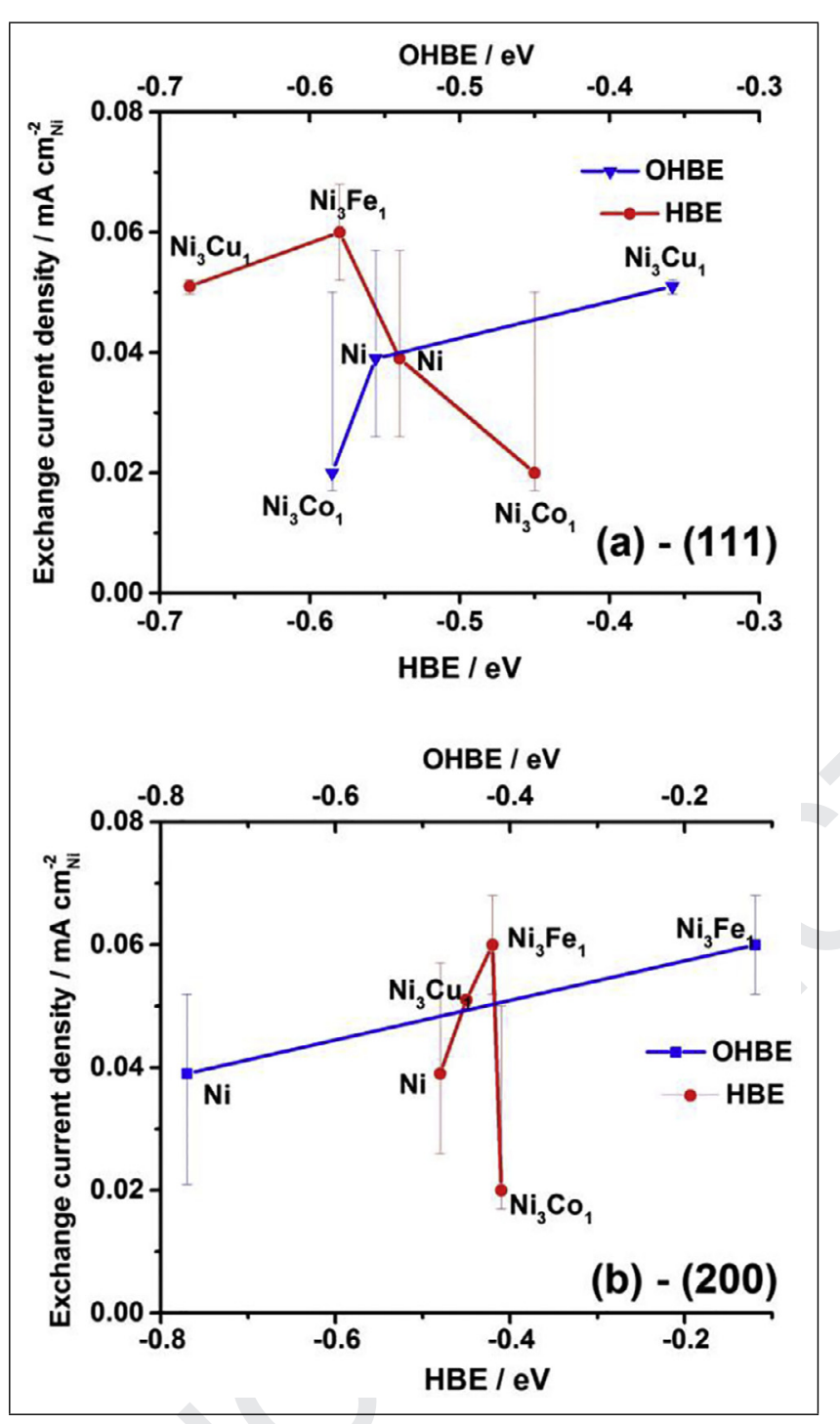

Correlation between the experimentally measured exchange current density values of the $\mathrm{Ni}$ and $\mathrm{Ni}$-metal catalysts, with the theoretically predicated HBE and OHBE values for (111) and (200) facets (Adopted from [42]).

used density functional theory to calculate the HBE and OHBE values for bare $\mathrm{Ni}$ and $\mathrm{Ni}$-metal catalysts, for a few metals $(\mathrm{Cu}, \mathrm{Co}, \mathrm{Fe})$, and suggested that the dopant metal onto $\mathrm{Ni}$ electrocatalyst have a significant effect onto the HBE and OHBE values, showing that these can be useful descriptors to evaluate different catalysts and eventually, relate these values to the exchange current densities. However, this is a first attempt, while this idea is waiting for further exploration, to finally unravel the full role of the hydroxide anions in the HOR.
Ideally, to find the best HOR electrocatalysts for AEMFCs we should then evaluate both HBE and OHBE and correlate the interaction between them and the exchange current densities. This ideal situation is schematically illustrated by a 'volcano plot', where both HBE and OHBE descriptors are simultaneously plotted for different electrocatalysts, as shown in Figure 3. The interaction between the electrocatalytic substrate and the $\mathrm{H}_{\mathrm{ad}}$ species, quantified by the HBE, is for instance, illustrated for a series of electrocatalysts with different OHBE values by a series of yellow curves. Similarly, interaction between the electrocatalytic substrate and the $\mathrm{OH}_{\mathrm{ad}}$ species, quantified by the OHBE, for electrocatalysts with different HBE values is shown by the green curves in Figure 3. The optimal fine-tuning of the adsorption energy of $\mathrm{H}_{\mathrm{ad}}$ and $\mathrm{OH}_{\mathrm{ad}}$, which may lead to the optimal HOR electrocatalysts can then be represented by a combination and simultaneous optimization of both HBE and OHBE descriptors. In that case, different fine-tuned HBE/OHBE combinations can lead to electrocatalysts highly active towards HOR for AEMFCs.

\section{Does water play a role in the AEMFC HOR?}

During operation of an AEMFC, the higher overpotential of the HOR at high $\mathrm{pH}$ anode electrode is also aggravated by the fact that water needs to be quickly removed from the catalyst layer. In contrast to the acidic counterpart, AEMFC operation involves generation of water as a product of the electrochemical HOR. Figure 4(a) shows a schematic diagram of an anode catalyst layer of AEMFCs. The porous of the anode catalyst layer needs not only to allow the hydrogen transport through the entire layer thickness, but also to 'accommodate' the water generated and allow its efficient removal. Two water molecules per reactant hydrogen molecule are generated (see Equation (2)), in absolute contrast to the HOR in acidic PEMFCs, where water is not taken direct part in the electrochemical reaction. This is a significant amount of water that is generated at the AEMFC anode, twice as much as water generated in the cathode of PEMFCs, per hydrogen molecule (or per electron produced), during the reduction of oxygen. In addition to that, in practical fuel cell systems running under standard gas stoichs, the volumetric flow of hydrogen is around 5 to 10 times lower than that of air. Therefore, with these extreme low hydrogen flows and the high amount of water generated by the HOR, water removal from AEMFC anodes is extremely challenging.

The accumulation of water in the AEMFC anode itself represents also a challenge for the supply of the reactants that as previously discussed, are sufficient to maximize the electrochemical HOR in the cell. Due to this fact, the electrolyte/electrode interface of AEMFCs can behave very differently from other similar electrochemical devices. The characterization of interfacial structure and understanding of fundamental characteristics of the AEMFC electrode/electrolyte interface may help shed 


\section{Figure 3}

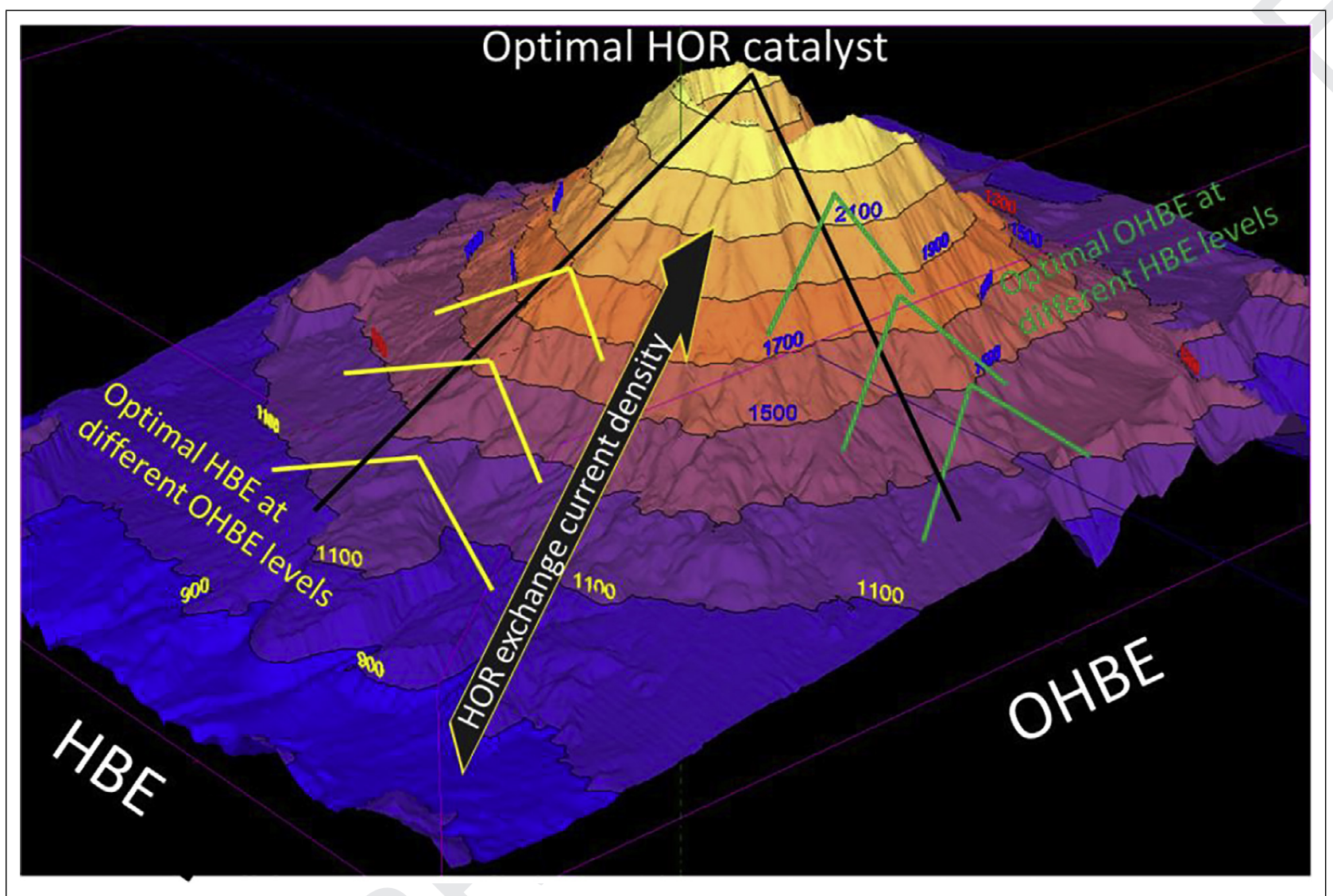

Schematic representation of an ideal simultaneous optimization of HBE and OHBE to evaluate and select electrocatalysts highly active towards HOR for AEMFCs.

light on designing and developing highly active nonprecious metal HOR electrocatalysts.

Figure 4(b) shows a schematic comparison of the triplephase boundary (TPB) for the electrooxidation of hydrogen for both acidic and alkaline fuel cell environments. As mentioned above, for AEMFCs the supply of hydrogen as well as the supply of $\mathrm{OH}^{-}$reactants to the TPB are critical for the HOR. Two $\mathrm{OH}^{-}$anions (of larger ion radius as compared with the $\mathrm{H}^{+}$cation radius in the acidic counterpart) should be transported through the solidanion-conducting electrolyte to react with the hydrogen in the TPB. In addition, as HOR occurs, water is generated in the surroundings of the catalyst. If water is not quickly removed from the TPB, a thin film of water will eventually cover the catalyst surface, creating additional resistance to the diffusive transport of the hydrogen to the TPB (see bottom Figure 4(b)). As previously discussed, removal of this water film from the fuel electrode is challenging, therefore we expect this film to be of significant thickness, affecting then the overall HOR kinetics. We can also assume that this water film affects the properties of the catalyst, for instance, affecting the HEB and maybe the OHBE and in turn, the HOR activity. Moreover, as the current density in the AEMFC device increases, the amount of water accumulated on the catalyst surrounding increases, generating thicker water films around the catalysts, which in turn are translated to increased resistance of the hydrogen transport through the water film. Taken into account all these effects water has onto the HOR electrocatalysis and AEMFC anodes, would provide a better understanding of the requirements for designing better hydrogen electrooxidation electrocatalysts for this technology.

\section{Concluding comments}

The field of AEMFCs has never been more active than in the past couple of years. However, to become a real alternative to the counterpart acidic fuel cells, AEMFCs should be able to equal PEMFG performance while based on affordable PGM-free electrocatalysts. In this work, we have remarked the challenges of HOR in AEMFCs. We highlighted the prohibitive overpotential 


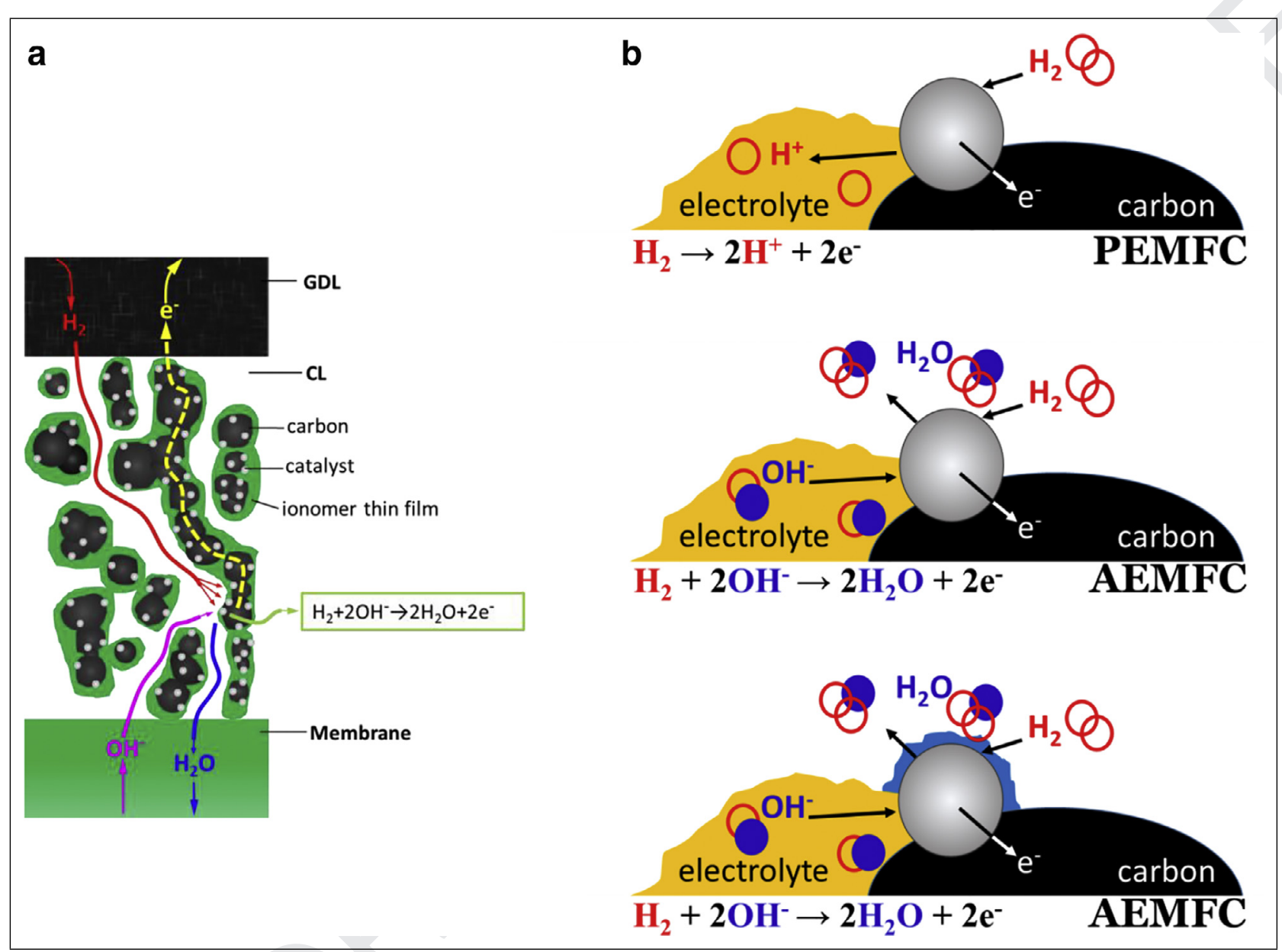

Schematic diagrams of the (a) AEMFC anode catalyst layer; and (b) a zoom-in into the triple-phase boundary of HOR, showing the differences between acidic and alkaline fuel cell environments.

of standard electrocatalysts towards HOR, the need to have two descriptors to achieve a better understanding of this reaction, and the importance and challenge of water in the AEMFC anodes. It is crucial to understand all these relations in order to develop highly active HOR PGM-free electrocatalysts for AEMFCs. In particular, increasing the understanding of the mechanism of reaction as well as the relationship between the HOR current density and the descriptors HBE and OHBE, will be of significant help in solving this major barrier in the technology, aiming for cells based completely on precious metal-free AEMFC electrodes.

\section{Acknowledgments}

This work was partially funded by the Nancy \& Stephan Grand Technion Energy Program (GTEP); by the European Union's Horizon 2020 research and innovation program [grant No. 721065]; by the Ministry of Science, Technology \& Space of Israel through the M.Era-NET Transnational Call 2015, NEXTGAME project [grant No. 3-12940], through the

Israel-Germany Batteries Collaboration Call 2017 [German grant No. 2675], and through grant No. 3-12948; by the Israel Science Foundation (ISF) [grant No. 1481/17]. The authors would also like to acknowledge the financial support of Melvyn \& Carolyn Miller Fund for Innovation, as well as the support of Planning \& Budgeting Committee/ISRAEL Council for Higher Education (CHE) and Fuel Choice Initiative (Prime Minister Office of ISRAEL), within the framework of "Israel National Research Center for Electrochemical Propulsion (INREP)",

\section{References and recommended reading}

Papers of particular interest, published within the period of review, have been highlighted as:

- Paper of special interest

- Paper of outstanding interest.

1. Varcoe JR, Atanassov P, Dekel DR, Herring AM, Hickner MA,

-. Kohl PA, Kucernak AR, Mustain WE, Nijmeijer K, Scott K, Xu'T, Zhuang L: Anion-exchange membranes in electrochemical energy systems. Energy Environ Sci 2014, 7:3135-3191. https://doi.org/10.1039/b000000x.

Unique comprehensive study showing a review of the use of anion exchange membranes for several electrochemical applications.

2. Gottesfeld S, Dekel DR, Page M, Bae C, Yan Y, Zelenay P, Kim YS: Anion exchange membrane fuel cells: current status and remaining challenges. J Power Sour 2018, 375:170-184. https://doi.org/10.1016/j.jpowsour.2017.08.010. 
3. Dekel DR: Alkaline membrane fuel cell (AMFC) materials and system improvement - state-of-the-art. ECS Trans 2013 50:2051-2052. https://doi.org/10.1149/05002.2051 ecst.

4. Miller HA, Lavacchi A, Vizza F, Marelli M, Di Benedetto F, D'Acapito F, Paska Y, Page M, Dekel DR: A Pd/C-CeO 2 anode catalyst for high-performance platinum-free anion exchange membrane fuel cells. Angew Chem Int Ed Engl 2016, 55:6004-6007. https://doi.org/10.1002/anie.201600647.

5. Dekel DR: Review of cell performance in anion exchange - membrane fuel cells. J Power Sour 2018, 375:158-169. https://doi.org/10.1016/j.jpowsour.2017.07.117.

Unique study showing a complete review of the cell performance of state-of-the-art hydrogen-fed anion exchange membrane fuel cells.

6. Omasta TJ, Peng X, Miller HA, Vizza F, Wang L, Varcoe JR, Dekel DR, Mustain WE: Beyond $1.0 \mathrm{~W} \mathbf{~ c m}^{-2}$ performance without platinum: the beginning of a new era in anion exchange membrane fuel cells. J Electrochem Soc 2018, 165:J3039-J3044. https://doi.org/10.1149/2.0071815jes.

7. Bellini M, Miller HA, Pagliaro M, Vizza F, Lenarda A, Fornasiero P, Marelli M, Evangelisti C, Jia Q, Mukrejee S, Jankovic J, Wang L, Varcoe J, Sharma C, Grinberg I, Davydova E, Dekel DR: Palladium-ceria catalysts with enhanced alkaline hydrogen oxidation activity for anion exchange membrane fuel cells. Energy Environ Sci 2018 Submitted.

8. Maurya S, Dumont JH, Villarrubia CN, Matanovic I, Li D, Kim YS, Noh S, Han J, Bae C, Miller HA, Fujimoto CH, Dekel DR: Surface adsorption affects the performance of alkaline anion-exchange membrane fuel cells. ACS Catal 2018, 8:9429-9439. https://doi.org/10.1021/acscatal.8b03227.

9. Omasta TJ, Wang L, Peng X, Lewis CA, Varcoe JR, Mustain WE: Importance of balancing membrane and electrode water in anion exchange membrane fuel cells. J Power Sour 2018, 375:205-213. https://doi.org/10.1016/j.jpowsour.2017.05.006

10. Wang L, Magliocca E, Cunningham EL, Mustain WE, Poynton SD, Escudero-Cid R, Nasef MM, Ponce-González J, Bance-Souahli R, Slade RCT, Whelligan DK, Varcoe JR: An optimised synthesis of high performance radiation-grafted anion-exchange membranes. Green Chem 2017, 19:831-843. https://doi.org/10.1039/C6GC02526A.

11. Dekel DR, Amar M, Willdorf S, Kosa M, Dhara S, Diesendruck CE: Effect of water on the stability of quaternary ammonium groups for anion exchange membrane fuel cell applications. Chem Mater 2017, 29:4425-4431. https://doi.org/10.1021/acs.chemmater.7b00958.

12. Dekel DR, Willdorf S, Ash U, Amar M, Pusara S, Dhara S, Srebnik S, Diesendruck CE: The critical relation between chemical stability of cations and water in anion exchange membrane fuel cells environment. J Power Sour 2018 , 375:351-360. https://doi.org/10.1016/j.jpowsour.2017.08.026.

13. Diesendruck CE, Dekel DR: Water - a key parameter in the stability of anion exchange membrane fuel cells. Curr Opin Electrochem 2018, 9:173-178.

https://doi.org/10.1016/j.coelec.2018.03.019.

14. Pusara S, Srebnik S, Dekel DR: Molecular simulation of quaternary ammonium solutions at low hydration levels. $J$ Phys Chem C 2018, 122:11204-11213.

https://doi.org/10.1021/acs.jpcc.8b00752.

15. Willdorf-Cohen S, Mondal AN, Dekel DR, Diesendruck CE: Chemical stability of poly(phenylene oxide)-based ionomers in anion exchange-membrane fuel cell environment. $J$ Mater Chem A 2018 Submitted.

16. Dekel DR, Rasin IG, Brandon S: Predicting performance stability in anion exchange membrane fuel cells. J. Power Sour 2018 Submitted.

Important manuscript showing for first time the effect of water on the performance stability of anion exchange membrane fuel cells.

17. Krewer U, Weinzierl C, Ziv N, Dekel DR: Impact of Carbonation Processes in Anion Exchange Membrane Fuel Cells. Elsevier Ltd; 2017. https://doi.org/10.1016/j.electacta.2017.12.093.
18. Lafforgue C, Chatenet M, Dubau L, Dekel DR: Accelerated stress test of $\mathrm{Pt} / \mathrm{C}$ nanoparticles in an interface with an anion-exchange membrane - an identical-location transmission electron microscopy study. ACS Catal 2018, 8:1278-1286. https://doi.org/10.1021/acscatal.7b04055.

19. Ziv N, Mustain WE, Dekel DR: The effect of ambient carbon dioxide on anion-exchange membrane fuel cells.

ChemSusChem 2018, 11:1136-1150. https://doi.org/10.1002/cssc.201702330.

20. Ziv N, Dekel DR: A practical method for measuring the true hydroxide conductivity of anion exchange membranes. Electrochem Commun 2018, 88:109-113. https://doi.org/10.1016/j.elecom.2018.01.021.

21. Ziv N, Mondal AN, Weissbach T, Holdcroft S, Dekel DR: Effect of $\mathrm{CO} 2$ on the properties of anion exchange membranes for fuel cell applications, Macromolecules. (2018).Submitted

22. Divekar AG, Park AM, Owczarczyk ZR, Seifert S, Pivovar BS, Herring AM: A study of carbonate formation kinetics and morphological effects observed on OH-form of Pfaem when exposed to air containing $\mathbf{C O}_{2}$. ECS Trans $2017, \mathbf{8 0}$ : 1005-1011.

23. Pandey TP, Peters BD, Liberatore MW, Herring AM: Insight on pure vs air exposed hydroxide ion conductivity in an anion exchange membrane for fuel cell applications. ECS Trans 2014 64:1195-1200.

24. Peng J, Roy AL, Greenbaum SG, Zawodzinski TA: Effect of $\mathbf{C O}_{2}$ absorption onion and water mobility in an anion exchange membrane. J Power Sour 2018, 380:64-75. https://doi.org/10.1016/j.jpowsour.2018.01.071.

25. Erikson H, Sarapuu A, Tammeveski K: Oxygen reduction reaction on silver catalysts in alkaline media: a minireview.

ChemElectroChem 2018:1-15. https://doi.org/10.1002/celc.201800913.

26. Gonen S, Elbaz L: Comparison of new metal organic framework-based catalysts for oxygen reduction reaction. Data Br 2018, 19:281-287. https://doi.org/10.1016/j.dib.2018.05.011.

27. Mamlouk M, Kumar SMS, Gouerec P, Scott K: Electrochemical and fuel cell evaluation of $\mathrm{CO}$ based catalyst for oxygen reduction in anion exchange polymer membrane fuel cells. $J$ Power Sour 2011, 196:7594-7600. https://doi.org/10.1016/j.jpowsour.2011.04.045.

28. Tarasevich MR, Davydova ES: Nonplatinum cathodic catalysts for fuel cells with alkaline electrolyte (Review). Russ $J$ Electrochem 2016, 52:193-219. https://doi.org/10.1134/S1023193516030113.

29. Xu X, Tan C, Liu H, Wang F, Li Z, Liu J, Ji J: Carbon black supported ultra-high loading silver nanoparticle catalyst and its enhanced electrocatalytic activity towards oxygen reduction reaction in alkaline medium. J Electroanal Chem 2013 , 696:9-14. https://doi.org/10.1016/j.jelechem.2013.02.018.

30. Davydova ES, Mukerjee S, Jaouen F, Dekel DR: Electrocatalysts

.. for hydrogen oxidation reaction in alkaline electrolytes. ACS Catal 2018, 8:6665-6690.

https://doi.org/10.1021/acscatal 8b00689.

Unique and comprehensive review study showing the state-of-the-art of hydrogen oxidation reaction in alkaline media.

31. Sheng W, Gasteiger HA, Shao-Horn Y: Hydrogen oxidation and evolution reaction kinetics on platinum: acid vs alkaline electrolytes. J Electrochem Soc 2010, 157: B1529-B1536.

32. Nørskov JK, Bligaard T, Rossmeisl J, Christensen CH: Towards the computational design of solid catalysts. Nat Chem 2009, 1:37-46. https://doi.org/10.1038/nchem.121.

33. Trasatti S: Work function, electronegativity, and electrochemical behaviour of metals: III. Electrolytic hydrogen evolution in acid solutions. J Electroanal Chem Interfacial Electrochem 1972, 39:163-184. 
34. Conway BE: Electrochemical processes involving $\mathbf{H}$ adsorbed on metal electrode surfaces: Interfacial Electrochemistry: Theory: Experiment, and Applications. Edited by Wieckowski A, 1st ed. CRC Press/Taylor \& Francis; 1999.

35. Greeley J, Markovic NM: The road from animal electricity to green energy: combining experiment and theory in electrocatalysis. Energy Environ Sci 2012, 5:9246-9256. https://doi.org/10.1039/c2ee21754f.

36. Elbert $\mathrm{K}, \mathrm{Hu}$ J, Ma Z, Zhang Y, Chen G, An W, Liu P, Isaacs HS, Adzic RR, Wang JX: Elucidating hydrogen oxidation/evolution kinetics in base and acid by enhanced activities at the optimized Pt shell thickness on the Ru core. ACS Catal 2015 , 5:6764-6772. https://doi.org/10.1021/acscatal.5b01670.

37. Ramaswamy N, Ghoshal S, Bates MK, Jia Q, Li J, Mukerjee S: - Hydrogen oxidation reaction in alkaline media: relationship between electrocatalysis and electrochemical double-layer structure. Nano Energy 2017, 41:765-771.

https://doi.org/10.1016/j.nanoen.2017.07.053.

Comprehensive study on the mechanism of reaction of electrooxidation of hydrogen in alkaline medium.

38. Durst J, Siebel A, Simon C, Hasché F, Herranz J, Gasteiger HA: New insights into the electrochemical hydrogen oxidation and evolution reaction mechanism. Energy Environ Sci 2014, 7:2255-2260. https://doi.org/10.1039/c4ee00440j.
39. Strmcnik D, Uchimura M, Wang C, Subbaraman R, Danilovic N,

- Van Der Vliet D, Paulikas AP, Stamenkovic VR, Markovic NM: Improving the hydrogen oxidation reaction rate by promotion of hydroxyl adsorption. Nat Chem 2013, 5:300-306. https://doi.org/10.1038/nchem.1574.

Very important study pointing out the challenge and importance of hydrogen oxidation reaction in anion exchange membrane fuel cells.

40. Zheng J, Sheng W, Zhuang Z, Xu B, Yan Y: Universal dependence of hydrogen oxidation and evolution reaction activity of platinum-group metals on $\mathrm{pH}$ and hydrogen binding energy. Sci Adv 2016, 2:1-9. https://doi.org/10.1126/sciadv.1501602.

41. Koper MTM: Hydrogen electrocatalysis: a basic solution. Nat Chem 2013, 5:255-256. https://doi.org/10.1038/nchem.1600.

42. Davydova E, Zaffran J, Dhaka K, Toroker M, Dekel D: Hydrogen oxidation on Ni-based electrocatalysts: the effect of metal doping. Catalysts 2018, 8:454.

https://doi.org/10.3390/catal8100454. 